ISSN: 1410-8917

Jurnal Kimia

Sains \&

Aplikasi
Jurnal Kimia Sains dan Aplikasi Journal of Scientific and Applied Chemistry

Journal homepage: http://ejournal.undip.ac.id/index.php/ksa

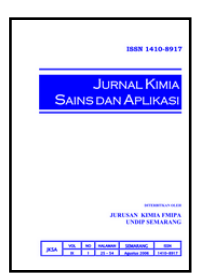

\title{
Peningkatan Derajat Deasetilasi Kitosan dari Cangkang Rajungan dengan Variasi Konsentrasi $\mathrm{NaOH}$ dan Lama Perendaman
}

\author{
Mike T. L. Tobing a , Nor Basid Adibawa Prasetya ${ }^{a}$, Khabibi ${ }^{\mathrm{a}^{*}}$ \\ a Analytical Chemistry Laboratory, Chemistry Department, Faculty of Sciences and Mathematics, Diponegoro University, Jalan Prof. \\ Soedarto, Tembalang, Semarang \\ * Corresponding author: khabibi@live.undip.ac.id
}

\section{Article Info}

Keywords:

chitin, chitosan, deacetylation degree

\section{Abstract}

Research on chitosan deacetylation degree from shrimp shell has been done. This study aims to determine the effect of $\mathrm{NaOH}$ concentration and soaking time to degrees of chitosan deacetylation. The study began by isolating chitin via the deproteination, demineralization, and depigmentation stages using $3 \mathrm{M} \mathrm{NaOH}, 1 \mathrm{M} \mathrm{HCl}$ and $\mathrm{H}_{2} \mathrm{O}_{2} 3 \%$ respectively. Furthermore, chitin obtained was analyzed by FTIR. Chitin production was performed by deacetylation of chitin by performing two variations i.e. variation of immersion time for $2,4,6$, and 8 hours and variation of $\mathrm{NaOH}$ concentration with concentrations of $40,50,60$, and $70 \%$. Furthermore, the chitosan obtained was analyzed by FTIR method. The results showed that the greatest deacetylation degree in soaking conditions for 8 hours with DD was $77.99 \%$ and $70 \% \mathrm{NaOH}$ concentration with DD was $77 \%$. The increase in deacetylation degree was influenced by the increase of immersion time and $\mathrm{NaOH}$ concentration.
Kata kunci:

kitin, kitosan, derajat deasetilasi

\begin{abstract}
Abstrak
Telah dilakukan penelitian tentang derajat deasetilasi kitosan dari cangkang rajungan. Penelitian ini bertujuan menentukan pengaruh konsentrasi $\mathrm{NaOH}$ dan lama perendaman terhadap derajat deasetilasi kitosan. Penelitian dimulai dengan mengisolasi kitin melalui tahap deproteinasi, demineralisasi, dan depigmentasi menggunakan $\mathrm{NaOH} 1 \mathrm{M}$, $\mathrm{HCl} 1 \mathrm{M}$ dan $\mathrm{H}_{2} \mathrm{O}_{2} \quad 3 \%$ secara berurutan. Selanjutnya kitin yang diperoleh dianalisis dengan FTIR. Produksi kitosan dilakukan dengan cara deasetilasi kitin dengan melakukan dua variasi yaitu waktu perendaman selama 2, 4, 6, dan 8 jam dan variasi konsentrasi $\mathrm{NaOH}$ dengan konsentrasi 40, 50, 60, dan 70\%. Selanjutnya kitosan yang diperoleh dianalisis dengan metode FTIR. Hasil penelitian menunjukkan bahwa derajat deasetilasi terbesar pada kondisi perendaman selama 8 jam dengan DD sebesar 77,99\% dan konsentrasi $\mathrm{NaOH} 70 \%$ dengan DD sebesar 77\%. Kenaikan derajat deasetilasi dipengaruhi oleh kenaikan waktu perendaman dan konsentrasi $\mathrm{NaOH}$.
\end{abstract}

\section{Pendahuluan}

Sebagai negara maritim, Indonesia mempunyai potensi hasil perikanan laut yang sangat melimpah, salah satu potensi ini adalah rajungan yang akan menghasilkan limbah yang berupa cangkang rajungan. Cangkang rajungan banyak mengandung kitin yang mencapai $18,70-32,20 \%$, tergantung pada jenis rajungan dan tempat hidupnya. Kitin dapat diisolasi dari limbah rajungan. Kitin, merupakan polimer berantai lurus tersusun atas residu $\mathrm{N}$-asetilglukosamina melalui ikatan $ß-(1,4)$ Melalui deasetilasi dengan basa kuat, kitin dapat diubah menjadi kitosan. Perlakuan ini mengakibatkan terlepasnya ikatan $\mathrm{N}$-asetil, sehingga mengubah satu $\mathrm{N}$-asetilglukosamin menjadi satuan glukosamin $[1,2]$.

Secara umum kitin banyak terdapat pada eksoskeleton atau kutikula serangga, crustacea, dan jamur [3]. Lebih dari 80.000 metrik ton kitin diperoleh 
dari limbah laut dunia per tahun [4], di Indonesia limbah kitin yang belum dimanfaatkan sebesar 56.200 metrik ton per tahun.

Sekitar 35\% dari cangkang rajungan mengandung kitin. Dari kitin rajungan dapat dihasilkan sekitar 80\% kitosan (No dan Meyer, 1997). Harga kitosan di pasaran dunia adalah sekitar US\$ 7.5/10g untuk kitosan dengan standar baik. Saat ini, $90 \%$ pasaran kitosan dunia dikuasai oleh Jepang dengan produksi lebih dari 100 juta ton setiap tahunnya [3]. Indonesia dengan potensi laut lebih luas daripada Jepang mempunyai peluang untuk mengambil bagian dari pasaran kitosan dunia.

Secara struktur kimia, kitosan adalah kitin yang telah mengalami deasetilasi (kehilangan gugus asetil). Isolasi kitin dari kulit udang/kepiting biasanya dilakukan dalam tiga tahap. Pertama, tahap penghilangan protein (deproteinasi). Tahap ini bertujuan untuk menghilangkan protein menggunakan $\mathrm{NaOH}$. Kedua, tahap penghilangan mineral (demineralisasi). Tahap ini dapat dilakukan dengan menambahkan larutan asam klorida. Tujuannya untuk menghilangkan mineral-mineral yang ada dalam tepung rajungan, terutama kalsium. Ketiga, tahap penghilangan warna. Tahap ini dapat dilakukan atau tidak tergantung keperluan. Penghilangan warna dapat menggunakan larutan oksidator, seperti asam oksalat, $\mathrm{H}_{2} \mathrm{O}_{2}$ atau $\mathrm{KMnO}_{4}$. Kitin kemudian di deasetilasi menggunakan basa kuat seperti $\mathrm{NaOH}$ dan $\mathrm{KOH}$ [5].

Derajat deasetilasi kitosan yang dihasilkan sangat dipengaruhi konsentrasi $\mathrm{NaOH}$ [6]. Larutan $\mathrm{NaOH}$ konsentrasi tinggi (>40\%) akan memutuskan ikatan gugus asetil dengan atom nitrogen dari kitin. Tingginya konsentrasi $\mathrm{NaOH}$ menyebabkan gugus fungsional amino $\left(-\mathrm{NH}_{3}{ }^{+}\right)$yang mensubstitusi gugus asetil kitin di dalam sistem larutan semakin aktif sehingga proses deasetilasi semakin baik. Melihat pengaruh dari larutan $\mathrm{NaOH}$ terhadap derajat deasetilasi kitosan, maka pada penelitian ini menggunakan variasi konsentrasi larutan $\mathrm{NaOH}$ mulai dari kontrasi 40\%, 50\%, 60\%, hingga 70\% sebagai dasar penelitian untuk meningkatkan derajat deasetilasi kitosan.

Selain konsentrasi $\mathrm{NaOH}$, derajat deasetilasi juga dipengaruhi lama perendaman dalam $\mathrm{NaOH}$ yang mengakibatkan terjadinya depolimerisasi memutuskan ikatan antara gugus karboksil dengan atom nitrogen. Melihat pengaruh dari perendaman dalam $\mathrm{NaOH}$ terhadap derajat deasetilasi kitosan , pada penelitian ini digunakan variasi lama perendaman dalam $\mathrm{NaOH}$ mulai dari waktu 2, 4, 6, hingga 8 jam untuk meningkatkan derajat deasetilasi kitosan.

\section{Metodologi}

\section{Isolasi Kitin}

Limbah cangkang rajungan dicuci dan dikeringkan. Selanjutnya dibuat serbuk rajungan dengan cara digiling kemudian diayak pada ukuran 100 mesh. Serbuk cangkang rajungan kering sebanyak 100 gram dideproteinasi dengan penambahan $500 \mathrm{~mL}$ larutan $\mathrm{NaOH} 1 \mathrm{M}$ selama 3 jam pada suhu $80^{\circ} \mathrm{C}$ dengan pengadukan terus menerus. Campuran disaring dan residu dicuci dengan akuades sampai netral, kemudian tahap demineralisasi dengan penambahan $500 \mathrm{~mL} \mathrm{HCl}$ $1 \mathrm{M}$, didiamkan selama 12 jam pada temperatur ruang. Campuran yang didapat lalu disaring dan residu dicuci dengan akuades hingga netral. Tahap pemutihan dilakukan dengan penambhan $100 \mathrm{~mL} \quad \mathrm{H}_{2} \mathrm{O}_{2} \quad 3 \%$ didiamkan selama 24 jam. Campuran disaring kemudian dicuci dengan akuades dikeringkan dalam oven pada suhu $80^{\circ} \mathrm{C}$ selama 4 jam. Hasil dianalisis dengan menggunakan spektrofotometri FTIR

\section{Variasi Konsentrasi $\mathrm{NaOH}$}

Kitin yang telah dihasilkan pada proses diatas dimasukkan dalam larutan $\mathrm{NaOH}$ dengan konsentrasi 40, 50, 60, dan $70 \%$ (berat) pada suhu $80^{\circ} \mathrm{C}$ sambil diaduk kecepatan konstan selama 4 jam. Campuaran disaring kemudian dicuci dengan aquades, dikeringkan dalam oven pada suhu $80^{\circ} \mathrm{C}$ selama 4 jam. Maka terbentuklah kitosan. Selanjutnya kitosan yang diperoleh dianalisis dengan menggunakan metode FTIR.

\section{Variasi Waktu Perendaman}

Kitin yang telah dihasilkan pada proses diatas dimasukkan dalam larutan $\mathrm{NaOH}$. Transformasi kitin menjadi kitosan dilakukan melalui deasetilasi dengan $\mathrm{NaOH} 60 \%$ sebanyak $500 \mathrm{~mL}$ sambil terus diaduk dengan variasi waktu perendaman 2, 4, 6, dan 8 jam pada suhu $80^{\circ} \mathrm{C}$. Campuran disaring kemudian dicuci dengan akuades, dikeringkan dalam oven pada suhu $80^{\circ} \mathrm{C}$ selama 4 jam. Maka terbentuklah kitosan. Selanjutnya kitosan yang diperoleh dianalisis dengan menggunakan metode FTIR. Penentuan derajat deasetilasi dilakukan dengan menggunakan persamaan Domszy dan Robrts.

\section{Hasil dan Pembahasan}

\section{Isolasi Kitin}

Proses isolasi kitin dari cangkang rajungan dilakukan melalui beberapa tahap. Tahap yang pertama adalah tahap deproteinasi yaitu tahap penghilangan protein dari cangkang rajungan dengan menggunakan reagen $\mathrm{NaOH} 1 \mathrm{M}$. Pada saat deproteinasi larutan menjadi agak mengental dan berwarna kemerahan. Larutan yang agak mengental tersebut karena adanya kandungan protein dari dalam crude kitin yang terlepas dan berikatan dengan ion $\mathrm{Na}^{+}$, membentuk natrium proteinat. Crude kitin hasil tahap deproteinisasi dicuci dengan aquades untuk menghilangkan sisa $\mathrm{NaOH}$ yang masih menempel pada crude kitin.<smiles>[Y10]CC(C)C(=O)C([R])N</smiles>

Gambar 1. Reaksi deproteinasi

Tahap selanjutnya yaitu demineralisasi, bertujuan untuk menghilangkan mineral atau senyawa 
anorganik yang terdapat pada crude kitin. Kandungan mineral utama didalam kulit udang adalah $\mathrm{CaCO}_{3}$. Proses demineralisasi dilakukan dengan menggunakan larutan $\mathrm{HCl}$ 1M. Pada proses ini, senyawa kalsium akan bereaksi dengan asam klorida menghasilkan kalsium klorida yang larut dalam air, gas $\mathrm{CO}_{2}$ dan air $\mathrm{HCl}$. Reaksi yang terjadi adalah sebagai berikut

$$
\mathrm{CaCO}_{3(\mathrm{~s})}+2 \mathrm{HCl} \rightarrow \mathrm{CaCl}_{2(\mathrm{aq})}+\mathrm{H}_{2} \mathrm{O}+\mathrm{CO}_{2(\mathrm{~g})}
$$

Crude kitin hasil tahap demineralisasi dicuci dengan aquades untuk menghilangkan sisa $\mathrm{HCl}$ yang masih menempel pada crude kitin. Setelah demineralisasi, maka crude kitin melalui tahap depigmentasi bertujuan untuk penghilangan warna (pigmen) yang terkandung dalam crude kitin, yaitu red-orange astaxanthin, suatu jenis karotenoid. Hasil yang diperoleh kemudian dicuci dengan akuades hingga $\mathrm{pH}$ netral. Produk yang dihasilkan adalah kitin kemudian dilakukan uji dengan menggunakan FTIR untuk mengidentifikasi gugus fungsi dan menentukan derajat deasetilasi. Derajat desetilasi diartikan sebagai persentase banyaknya gugus asetil yang hilang dan digantikan dengan $-\mathrm{H}$ saat proses deasetilasi, Berdasarkan perhitungan Base line, diperoleh derajat deasetilasi kitin sebesar 55,74\%. Derajat deasetilasi tersebut menunjukkan adanya gugus $\mathrm{NH}_{2}$ sebesar $55,74 \%$ dan gugus asetil yang tersisa pada kitin sebesar $44.26 \%$. Spektra FTIR kitin ditunjukkan pada gambar 2

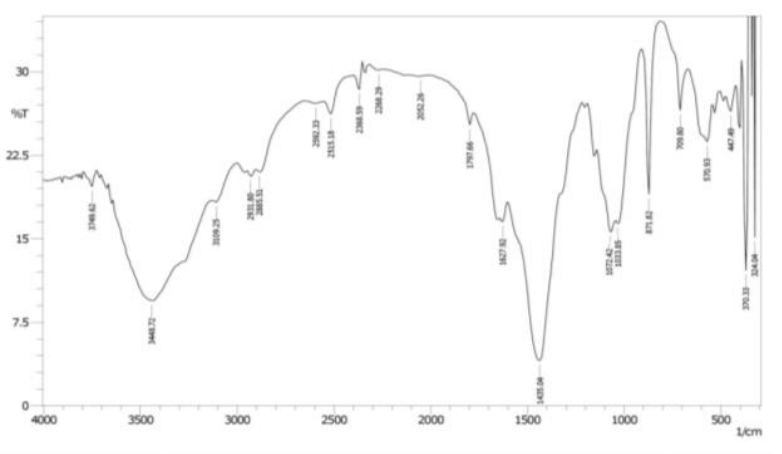

Gambar 2. Spektra FTIR Kitin

Tabel 1. Bilangan gelombang dan gugus yang terdapat pada kitin sesuai

\begin{tabular}{cc}
\hline $\begin{array}{c}\text { Bilangan gelombang } \\
\left(\mathrm{cm}^{-1}\right)\end{array}$ & Prediksi gugus \\
\hline 3448,72 & Uluran O-H dan uluran \\
2931,80 & Regangan C-H alifatik \\
1627,92 & Uluran C=O amida \\
1427,32 & sekunder \\
1072,42 & C-H alkil \\
\hline
\end{tabular}

Berdasarkan spektra yang dihasilkan pada gambar 2, terlihat ada beberapa puncak khas yang menunjukkan ciri spesifik struktur kitosan. Misalnya pada puncak $1072,42 \mathrm{~cm}^{-1}$ yang menunjukkan adanya gugus eter, $\mathrm{CH}_{3}$ pada bilangan gelombang $1427,32 \mathrm{~cm}^{-1}$, puncak $1627,92 \mathrm{~cm}^{-1}$ menunjukkan adanya gugus $\mathrm{C}=\mathrm{O}$ yang menunjukkan keberadaan amida, puncak 2931,80 $\mathrm{cm}^{-1}$ menunjukkan adanya uluran $\mathrm{C}-\mathrm{H}$, puncak 3448,72 $\mathrm{cm}^{-1}$ yang menunjukkan adanya gugus alkohol yang berimpitan dengan uluran $\mathrm{NH}$ dan beberapa puncak serapan lain yang memperkuat adanya struktur khitosan pada sampel yang diuji.

\section{Pengaruh Variasi Konsentrasi NaOH dalam Proses Transformasi Kitin}

Kitin hasil isolasi dilakukan proses deasetilasi menggunakan variasi konsentrasi $\mathrm{NaOH}$. Untuk menentukan konsentrasi $\mathrm{NaOH}$ maksimal, maka proses deasetilasi ini dilakukan dengan konsentrasi $\mathrm{NaOH}$ bervariasi yaitu 40, 50, 60 dan 70\%. Hasilnya di FTIR sebagaimana pada Gambar 3, 4, 5 dan 6. Penggunaan konsentrasi $\mathrm{NaOH}$ yang tinggi pada proses deasetilasi diharapkan akan menghasilkan rendemen kitosan yang memiliki derajat deasetilasi tinggi. Hal ini disebabkan gugus fungsional amino $\left(-\mathrm{NH}_{3}^{+}\right)$yang mensubtitusi gugus asetil kitin di dalam sistem larutan semakin aktif, maka semakin sempurnalah proses deasetilasi.

Penggunaan $\mathrm{NaOH}$ konsentrasi tinggi digunakan karena struktur kitin yang tebal dan ikatan hidrogen mempunyai karboksil pada rantai berikutnya serta untuk memutuskan ikatan antara gugus karboksil dengan atom nitrogen. Hal ini sesuai pula dengan pendapat Martinou $d k k$. [7] yang menyatakan bahwa larutan $\mathrm{NaOH}$ mampu merubah konformasi kitin yang sangat rapat menjadi renggang sehingga lebih mudah terekspos untuk mendeasetilasi polimer kitin.

Hasil percobaan dapat dilihat pada grafik pengaruh penambahan konsentrasi $\mathrm{NaOH}$, menunjukkan bahwa derajat deasetilasi terbesar terjadi pada konsentrasi $\mathrm{NaOH} 70 \%$ yaitu sebesar $77 \%$. Konsentrasi $\mathrm{NaOH}$ semakin meningkat mengakibatkan derajat deasetilasi meningkat. Konsentrasi $\mathrm{NaOH}$ yang semakin besar yaitu dari $40 \%$ menjadi $50 \%$ meningkatkan derajat deasetilasi sebesar $1.12 \%$ (dari $72.80 \%$ menjadi $74 . \%$ ). Pada konsentrasi $\mathrm{NaOH}$ yang ketiga dari $50 \%$ menjadi $60 \%$ hanya meningkatkan derajat deasetilasi sebesar $0.85 \%$ (dari 74.\% menjadi 74.85\%). Kemudian pada konsentrasi $\mathrm{NaOH}$ yang terakhir meningkatkan derajat deasetilasi sebesar $2.15 \%$ ( dari $74.85 . \%$ menjadi $77 \%$ ).

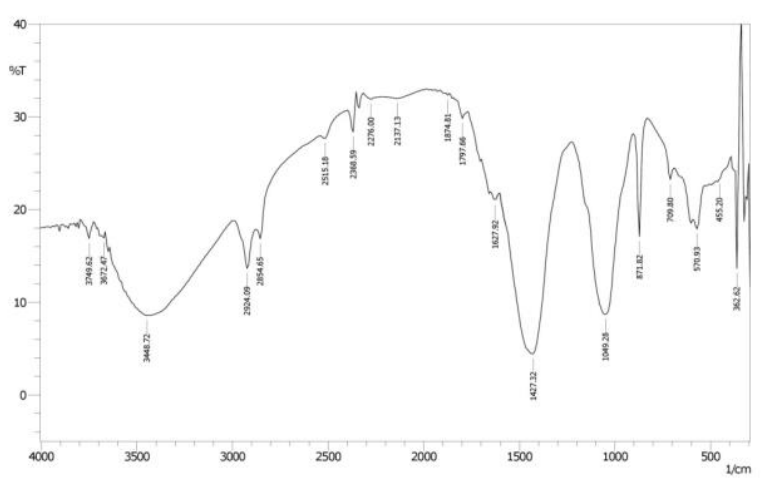

Gambar 3. Spektra FTIR Kitosan dengan variasi konsentrasi $\mathrm{NaOH} 40 \%$ 


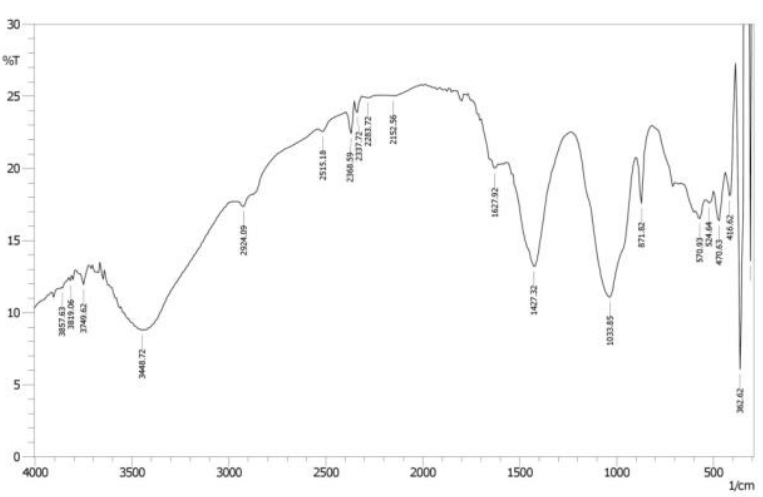

Gambar 4. Spektra FTIR Kitosan dengan variasi konsentrasi $\mathrm{NaOH} 50 \%$

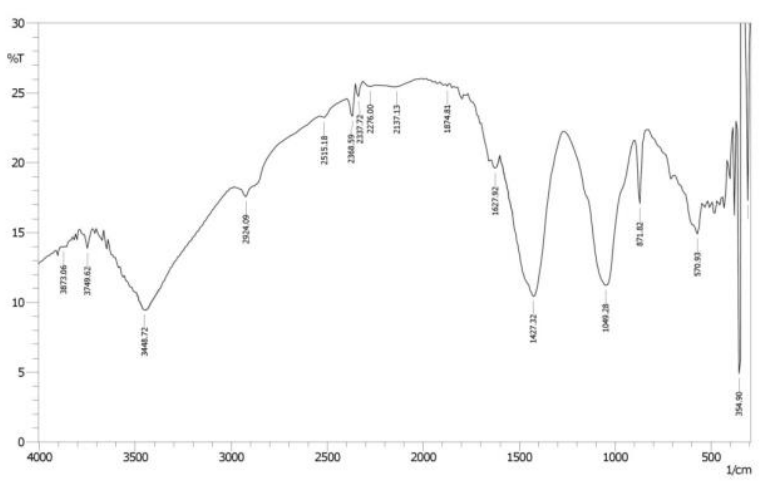

Gambar 5. Spektra FTIR Kitosan dengan variasi konsentrasi $\mathrm{NaOH} 60 \%$

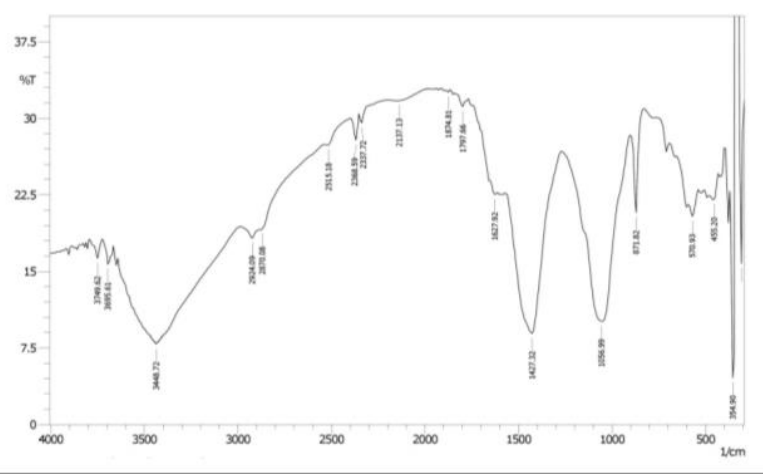

Gambar 6. Spektra FTIR Kitosan dengan variasi konsentrasi $\mathrm{NaOH} 70 \%$

Tabel 2. Hasil perhitungan derajat deasetilasi kitosan pada variasi konsentrasi $\mathrm{NaOH}$ selama 4 jam pada suhu $80^{\circ} \mathrm{C}$

\begin{tabular}{cc}
\hline Konsentrasi $\mathrm{NaOH}(\%)$ & Berat kitosan (gram) \\
\hline 40 & 6,75 \\
50 & 6,44 \\
60 & 6,59 \\
70 & 5,12 \\
\hline
\end{tabular}

Hasil serupa juga diperoleh oleh penelitian Azhar,dkk (2010) terhadap kulit udang yang menyatakan derajat deasetilasi produk yang direndam dengan $\mathrm{NaOH} 40 \%$ dan $50 \%$ pada suhu $100^{\circ} \mathrm{C}$ dengan waktu perendaman kitin 300 menit menghasilkan derajat deasetilasi $59.31 \%$, dan $66.67 \%$ yang juga meningkat. Perbedaan nilai derajat deasetilasi ini mungkin karena sampel kulit udang yang digunakan masih dalam bentuk kasar (belum diayak) sehingga reaksi penghilangan gugus asetil berjalan dengan lambat.

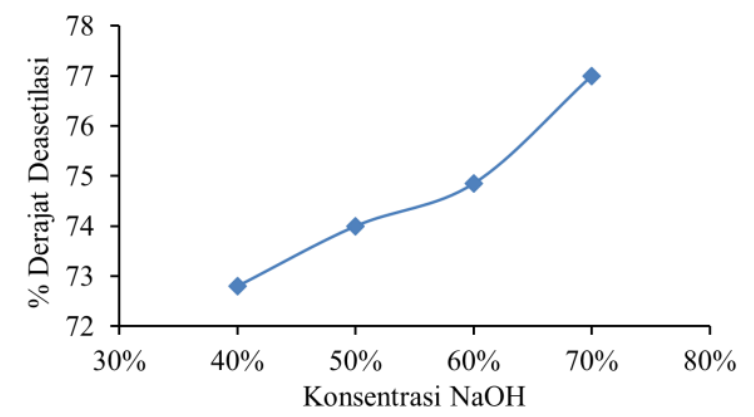

Gambar 7. Pengaruh Penambahan Konsentrasi $\mathrm{NaOH}$ terhadap Nilai DD

Pengaruh Variasi Lama Perendaman dalam Proses Transformasi Kitin

Proses transformasi kitin dengan variasi lama perendaman digunakan untuk mengetahui lama perendaman optimum reagen untuk proses pembentukan kitosan dengan derajat deasetilasi terbesar. Lama perendaman kitin dalam $\mathrm{NaOH}$ berpengaruh terhadap pemecahan rantai molekul kitin [7]. Perendaman dalam $\mathrm{NaOH}$ dilakukan terhadap sampel kitin dalam bentuk tepung dengan ukuran 100 mesh. Penepungan dilakukan agar proses deasetilasi dapat berlangsung lebih cepat dan sempurna, karena semakin luasnya permukaan yang dapat diakses oleh larutan alkali.

Derajat deasetilasi adalah suatu parameter mutu yang menunjukkan gugus asetil yang dapat dihilangkan dari kitin. Semakin tinggi derajat deasetilasi kitosan, maka gugus asetil yang terdapat dalam kitosan tersebut semakin sedikit [5]. Pengaruh lama perendaman terhadap derajat deasetilasi dapat dilihat pada grafik pengaruh waktu perendaman $\mathrm{NaOH}$ terhadap derajat deasetilasi sebagaimana pada Gambar 7, 8, 9 dan 10. Derajat deasetilasi terbesar didapatkan pada perendaman $\mathrm{NaOH} 60 \%$ pada $80^{\circ} \mathrm{C}$ selama 8 jam sebesar 77.99\%. Lama perendaman $\mathrm{NaOH}$ meningkat mengakibatkan derajat deasetilasi meningkat, sedangkan perendaman yang semakin tinggi dari 2 jam sampai 4 jam meningkatkan derajat deasetilasi sebesar $3.31 \%$ (dari $71.54 \%$ menjadi $74.85 \%$ ). Pada perendaman yang ketiga dari 4 jam menjadi 6 jam hanya meningkatkan derajat deasetilasi sebesar $1.35 \%$ (dari $74.85 \%$ menjadi $76.2 \%$ ). Kemudian pada perendaman yang terakhir meningkatkan derajat deasetilasi sebesar $1.79 \%$ (dari $76.20 \%$ menjadi $77.99 \%$ ). Besaran peningkatan derajat deasetilasi menunjukkan bahwa lama perendaman berpengaruh terhadap kenaikan derajat deasetilasi. 


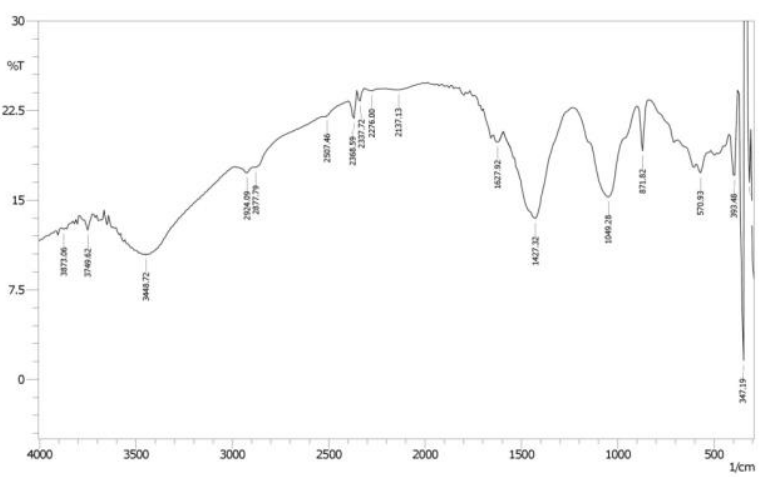

Gambar 8. Spektra FTIR Kitosan dengan variasi Perendaman selama 2 jam

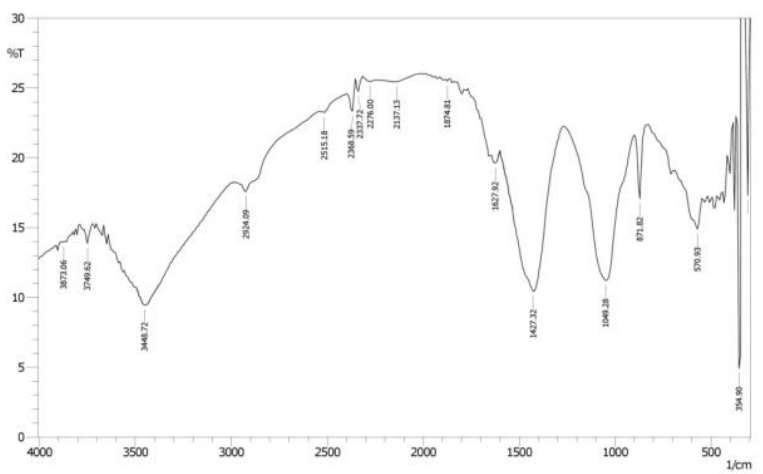

Gambar 9. Spektra FTIR Kitosan dengan variasi Perendaman selama 4 jam

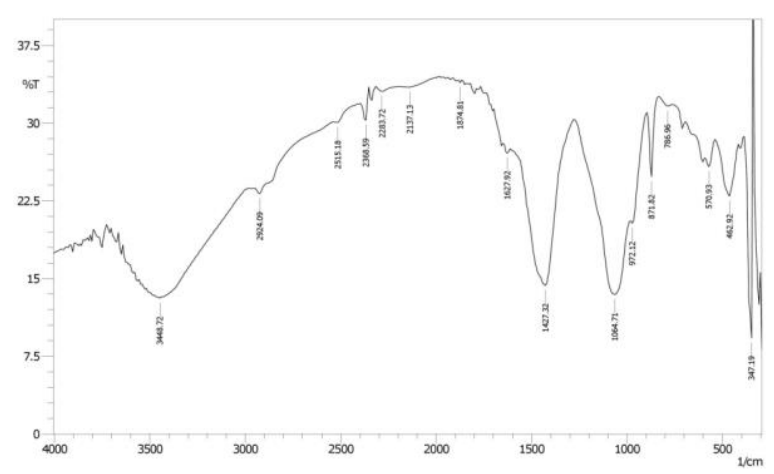

Gambar 10. Spektra FTIR Kitosan dengan variasi Perendaman selama 6 jam

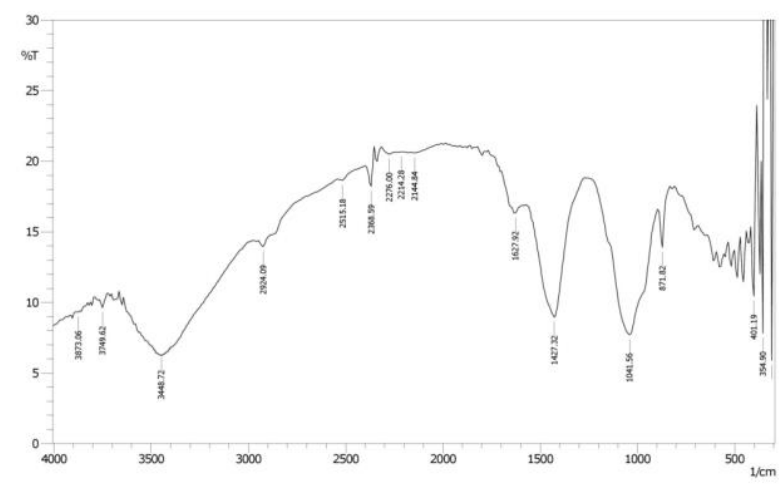

Gambar 11. Spektra FTIR Kitosan dengan variasi Perendaman selama 8 jam
Tabel 3. Hasil perhitungan derajat deasetilasi kitosan pada variasi lama waktu perendaman dengan konsentrasi $60 \%$ dan suhu $80^{\circ} \mathrm{C}$

\begin{tabular}{cc}
\hline $\begin{array}{c}\text { Waktu Perendaman } \\
\text { (jam) }\end{array}$ & Berat kitosan (gram) \\
\hline 40 & 6,47 \\
50 & 6,59 \\
60 & 6,19 \\
70 & 5,04 \\
\hline
\end{tabular}

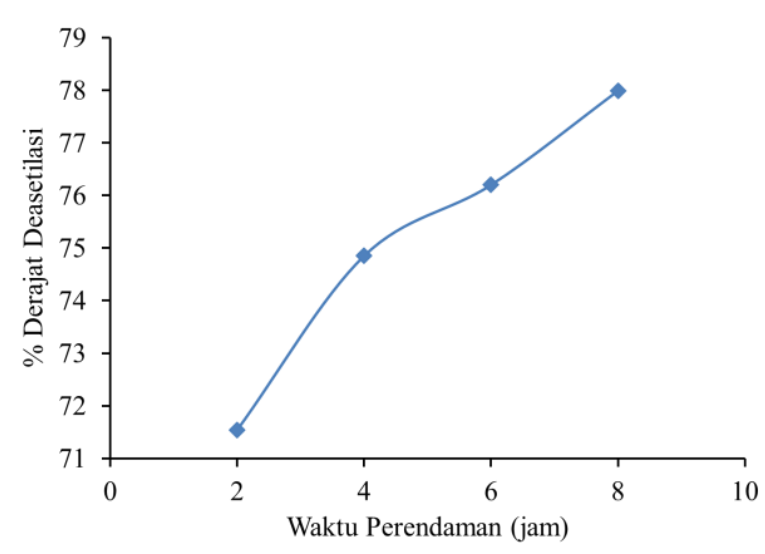

Gambar 12. Pengaruh Perpanjangan Waktu Perendaman Naoh terhadap Nilai DD

Hasil serupa juga diperoleh oleh penelitian A Emmawati, dkk (2000) yang menyatakan derajat deasetilasi produk yang direndam dengan $\mathrm{NaOH} 60 \%$ pada suhu $60^{\circ} \mathrm{C}$ dengan waktu perendaman kitin 60,90 , 120 dan 180 menit menghasilkan derajat deasetilasi $50,88 \%, 53,26 \%$, 54,65\%, dan $64,31 \%$ yang juga meningkat. Perbedaan nilai derajat deasetilasi ini karena suhu perendaman $\mathrm{NaOH}$ yang digunakan lebih rendah $\left(60^{\circ} \mathrm{C}\right)$. Kondisi awal kitin, seperti derajat deasetilasi awal, juga berpengaruh terhadap perbedaan derajat deasetilasi akhir. Dalam hal ini, penelitian Emmawati dkk. [8] kondisi awal kitin yang dihasilkan sebesar $42,22 \%$. Sementara dalam penelitian ini, digunakan kitin dengan derajat deasetilasi awal sudah cukup besar, yaitu $55,74 \%$.

Dengan demikian kenaikan derajat deasetilasi dipengaruhi oleh kenaikan perpanjangan waktu perendaman, sedangkan lama perendaman dan konsentrasi $\mathrm{NaOH}$ juga berpengaruh terhadap pemecahan rantai molekul.

\section{Kesimpulan}

Kitosan dapat dihasilkan dari cangkang rajungan. Pada penelitian ini dilakukan variasi lama perendaman selama 2, 4, 6 dan 8 jam dalam transformasi kitin dan memberikan derajat deasetilasi yang maksimal pada perendama selama 8 jam sebesar $77,99 \%$ Pada penelitian ini dilakukan variasi konsentrasi $\mathrm{NaOH} 40$, 50, 60 dan $70 \%$ dan memberikan derajat deasetilasi yang maksimal pada konsentrasi $\mathrm{NaOH} 70 \%$ sebesar $77 \%$ 


\section{Daftar Pustaka}

[1] M Enick Robert, J Beckman Eric, The Chitin Chemistry, (1992)

[2] George AF Roberts, Structure of chitin and chitosan, in: Chitin Chemistry, Springer, 1992, pp. 1-53.

[3] Iason Tsigos, Aggeliki Martinou, Dimitris Kafetzopoulos, Vassilis Bouriotis, Chitin deacetylases: new, versatile tools in biotechnology, Trends in Biotechnology, 18, 7, (2000) 305-312 http://dx.doi.org/10.1016/S0167-7799(00)01462-1

[4] Reetarani S. Patil, Vandana Ghormade, Mukund V. Deshpande, Chitinolytic enzymes: an exploration, Enzyme and Microbial Technology, 26, 7, (2000) 473483 http://dx.doi.org/10.1016/S01410229(00)00134-4

[5] Dietrich Knorr, Functional Properties of Chitin and Chitosan, Journal of Food Science, 47, 2, (1982) 593595 http://dx.doi.org/10.1111/j.13652621.1982.tb10131.x

[6] Soottawat Benjakul, Pairat Sophandora, Chitosan production from carapace and shell of black tiger shrimp (Panaeus monodon), Asean Food Journal (Malaysia), (1993)

[7] A. Martinou, D. Kafetzopoulos, V. Bouriotis, Chitin deacetylation by enzymatic means: monitoring of deacetylation processes, Carbohydrate Research, 273, 2, (1995) 235-242 http://dx.doi.org/10.1016/00086215(95)00111-6

[8] Aswita Emmawati, Betty Sri Laksmi Jenie, Yusro Nuri Fawzya, Produksi Kitosan Dengan Kombinasi Perlakuan Kimia Dan Enzimatis Menggunakan $\mathrm{NaOH}$ dan Kitin Deasetilase, Sekolah Pascasarjana, Institut Pertanian Bogor, Bogor 